Volume 3 Nomor 1, Maret 2021, Halaman 53 - 60.

\title{
Pemanfaatan Buah Sawo (Manilkara Zapota) Untuk Menghasilkan Keripik Dan Sirup Di Desa Pawidean
}

\author{
Eva Yuliana ${ }^{1)}$, Lissa $^{21}$, Nur Subkhi ${ }^{3)}$ \\ 1, 2, 3) Program Studi Pendidikan Biologi, FKIP Universitas Wiralodra \\ Email :evayuliana@unwir.ac.id ${ }^{1}$, lissa@unwir.ac.id ${ }^{2}$, nursubkhi@unwir.ac.id ${ }^{3}$
}

\begin{abstract}
Abstrak
Buah sawo banyak terdapat di desa Pawidean, namun pemanfaatan buah tersebut tidak maksimal. Pemanfaatan buah sawo sebatas konsumsi buah secara langsung. Oleh sebab itu perlu adanya kegiatan untuk memaksimalkan pemanfaatan sumber daya alam. Tujuan kegiatan ini ialah untuk memanfaatkan produk unggulan atau komoditas unggulan buah sawo menjadi produk keripik dan sirup sehingga dapat memberikan manfaat suatu pengetahuan tentang pengolahan buah sawo menjadi keripik dan sirup. Metode yang digunakan dalam kegiatan ini yaitu dengan cara sosialisasi atau penyuluhan kepada ibu-ibu Desa Pawidean. Kegiatan ini dilakukan pada tanggal 24 November 2020 dengan dihadiri sebanyak 15 Ibu-Ibu desa Pawidean.

Kata Kunci: Penyuluhan, Sawo, Keripik, Sirup.
\end{abstract}

\begin{abstract}
Abtract
Sapodilla fruit is widely available in Pawidean village, but the utilization of the fruit is not optimal. Utilization of sapodilla fruit is limited to direct consumption of fruit. Therefore, it is necessary to have activities to maximize the use of natural resources. The purpose of this activity is to utilize superior products or superior commodities of sapodilla fruit into chips and syrup products so that they can provide benefits with knowledge about processing sapodilla fruit into chips and syrup. The method used in this activity is by means of socialization or counseling to the mothers of Pawidean Village. This activity was carried out on November 24, 2020, attended by 15 women from Pawidean village.
\end{abstract}

Keywords: Counseling Sapodilla, Chips, Syrup.

DOI: https://doi.org/10.31943/abdi.v3i1.30

\section{A. Pendahuluan}

Sawo (Manilkara zapota) merupakan tumbuhan tropis yang mudah beradaptasi sehingga mudah dibudidayakan di berbagai negara termasuk di Indonesia, sawo banyak diusahakan di lahan pekarangan dan sangat mudah dijumpai di pasaran. Kualitas buah sawo sangat ditentukan oleh rasa manis (kandungan padatan terlarut/KPT). Menurut Kusumiyati, dkk (2017) bahwa pengaruh suhu pada lamanya penyimpanan buah sawo dapat berdampak pada 
ABDI WIRALODRA

JURNAL PENGABDIAN KEPADA MASYARAKAT
ISSN 2656-5501 (Print)

ISSN 2714-8041 (Online)

kualitas buah sawo, yaitu perubahan pada nilai kekerasan buah, kadar air, total padatan terlarut, dan perubahan warna. Menurut Rismunandar (1983) rasa manis pada buah sawo karena kandungan utama glukosa sebesar 4,2 gram/100 gram daging buah dan fruktosa 3,8 gram/ 100 gram daging buah. Kedua jenis gula ini mudah diserap oleh tubuh.

Desa Pawidean merupakan salah satu desa di Kecamatan Jatibarang Kabupaten Indramayu. Umumnya penduduk setempat memiliki atau pencaharian sebagai petani, seperti petani sawah, mangga, pisang, pepaya, sawo, dan lain-lain. Oleh karena itu di desa ini memiliki sumber daya pangan yang cukup banyak. Sudah banyak olahan mangga di desa ini, namun tidak adanya warga yang tergerak untuk membuat olahan berbahan dasar sawo dan hanya langsung memakan atau menjual buahnya. Selain itu, Ibu-ibu di Desa Pawidean masih kurangnya pengetahuan tentang pengolahan makanan yang berbahan dasar dari buah sawo sehingga perlu adanya penyuluhan atau sosialisasi agar dapat menambah pengetahuan dan wawasan.

Menurut Jufriyanto (2019) salah satu cara dalam pengembangan ekonomi adalah dengan mengoptimalkan produk unggulan atau komoditi unggulan agar memberikan manfaat dalam pengoptimalan sumber daya yang ada dan mamapu memberikan suatu pengetahuan tentang bahan yang memiliki nilai ekonomi lebih. Menurut Hidayah (2010) menyatakan bahwa komoditas unggulan adalah komoditas andalan yang memiliki posisi strategis untuk dikembangkan di suatu wilayah.

Salah satu cara untuk mengoptimalkan produk unggulan adalah dengan melakukan kegiatan pengabdian melalui penyuluhan dan pelatihan pembuatan produk yang bisa di jadikan usahan rumahan berskala kecil yaitu Keripik Sawo dan Sirop Buah Sawo kepada Ibu-Ibu di Desa Pawidean. Kegiatan ini diharapkan dapat mengoptimalkan dan meningkatkan pengetahuan atau wawasan juga dapat menambah nilai jual dari buah sawo itu sendiri.

\section{B. Metode}

Kegiatan ini dilakukan dengan menggunakan metode sosialisasi/penyuluhan kepada warga Desa Pawidean Kecamatan Jatibarang. Dengan sampelnya ibu-ibu warga 
sekitar di Desa Pawidean. Kegiatan Pengabdian Kepada Masyarakat (PKM)

dilaksanakan selama bulan November 2020.

Adapun langkah-langkah pelaksanaan pengabdian ini sebagai berikut:

1. Melakukan survey ke lokasi untuk melihat potensi lokal desa

2. Melakukan wawancara dengan warga desa sekitar untuk mengetahui pemanfaatan potensi lokal

3. Menentukan produk yang akan di buat menjadi produk unggulan

4. Melakukan uji coba pembuatan produk untuk di sosialisasikan

5. Menentukan lokasi yang baik untuk di lakukan sosialisasi

6. Melaksanakan proses sosialisasi kepada ibu-ibu warga sekitar

7. Pemberian lembar kuesioner untuk menengetahui hasil produk yang dibuat Sosialisasi kepada masyarakat di laksanakan pada tanggal 24 November 2020 yang bertempat di rumah salah satu warga Desa Pawidean. Sosialisasi di lakukan dengan cara memberikan pengetahuan kepada warga mengenai manfaat sawo, cara pengolahan sawo untuk dijadikan produk. Sosialisasi di ikuti oleh 15 ibu-ibu warga Pawidean.

\section{Hasil dan Pembahasan}

Kegiatan PKM ini berupa penyuluhan produk dari buah sawo di Desa Pawidean Kecamatan Jatibarang, yang dilaksanakan pada tanggal 24 November 2020 dimulai pada pukul 09.00 sampai dengan pukul 11.00 di rumah salah satu warga desa Pawidean. Kegiatan ini dihadiri oleh 15 Ibu - Ibu warga Pawidean. Sosialisasi ini bertujuan untuk memberikan sosialisasi atau penyuluhan memaksimalkan potensi lokal berupa pemanfaatan buah sawo sebagai produk baru (keripik dan sirup sawo) yang dihasilkan oleh masyarakat dan melatih masyarakat menjadi lebih kreatif dalam mengolah hasil buah-buahan mereka menjadi produk baru yang bernilai jual. Sosialisasi disambut antusisas oleh warga, hal ini dibuktikan dari antusiasnya dalam bertanya dan menjawab pertanyaan terhadap produk keripik sawo dan sirup sawo dari cara pembuatan yang cukup mudah untuk dibuat sendiri. 


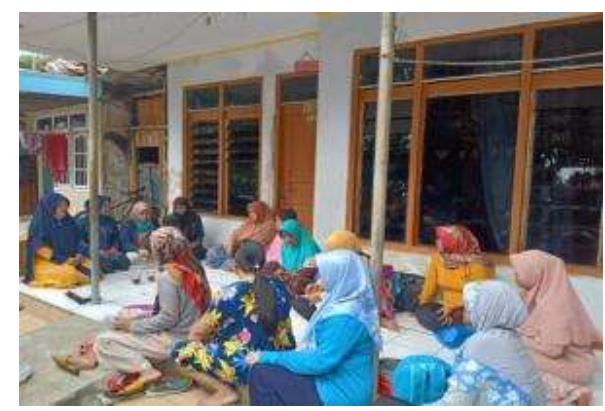

Gambar 1. Kegiatan sosialisasi Pembuatan Keripik Sawo dan Sirup Sawo

Kegiatan pengabdian ini dilakukan untuk memberikan wawasan atau pengetahuan kepada Ibu-Ibu di desa Pawidean. Kegiatan melalui beberapa langkah yang dilakuakan yaitu:

Kegiatan pertama yaitu melakukan survey lokasi guna melihat potensi desa. Kegiatan survey dilakukan dengan melakukan potensi desa yang ada di wilayah Indramayu yang dapat dijadikan pengabdian. Hal ini dikarenakan atas beberapa pertimbangan, diantaranya potensi alam di wilayah, pemanfaatan sumber daya alam yang belum maksimal, terdapat sentra penjualan oleh-oleh di wilayah tersebut. Berdasarkan pertimbangan tersebut maka desa Pawidean dijadikan tempat untuk melakukan kegiatan ini.

Kegiatan kedua yaitu melakukan wawancara. Kegiatan ini dilakuakan untuk mengetahui potensi sumber daya alam yang dimiliki di desa Pawidean agar dapat dimanfaatkan secara maksimal. Wawancara dilakukan dengan warga sekitar dengan bentuk tanya jawab. Hasil wawancara ini digunakan sebagai dasar untuk menentukan potensi daya alam lokal yang akan dijadikan produk atau olahan buah. Kegiatan ketiga yaitu menentukan potensi lokal untuk dijadikan produk unggulan. Potensi lokal yang digunakan adalah pemanfaatan buah sawo yang banyak tersebat di desa Pawidesan. Sawo merupakan buah yang berasa manis dan memiliki kandungan gula yang cukup banyak. Selain kandungan gula yang banyak, sawo juga memiliki kandungan lain. Menurut Jufriyanto (2019) daging buah sawo memiliki kandungan lemak, protein, vitamin A, B dan C, mineral besi, kalsium serta fosfor. Kandungan kalium 193mg/100g, natrium $12 \mathrm{mg} / 100 \mathrm{gr}$ dengan perbandingan kandungan kalium dan natrium sebesar 16:1 menjadikan sawo sangant baik untuk jantung dan pembuluh darah. Selain kandungan tersebut, sawo memiliki kandungan gizi sebesar 92,0 kal kalori. Dengan kandungan tersebut maka dilakukan inovasi memanfaatkan buah sawo dijadikan keripik dan sirup sawo. 
Kegiatan keempat yaitu melakuakn uji coba pembuatan produk sebelum dilakukan sosialisasi kepada warga. Uji coba ini dapat dilihat pada tabel di bawah ini:

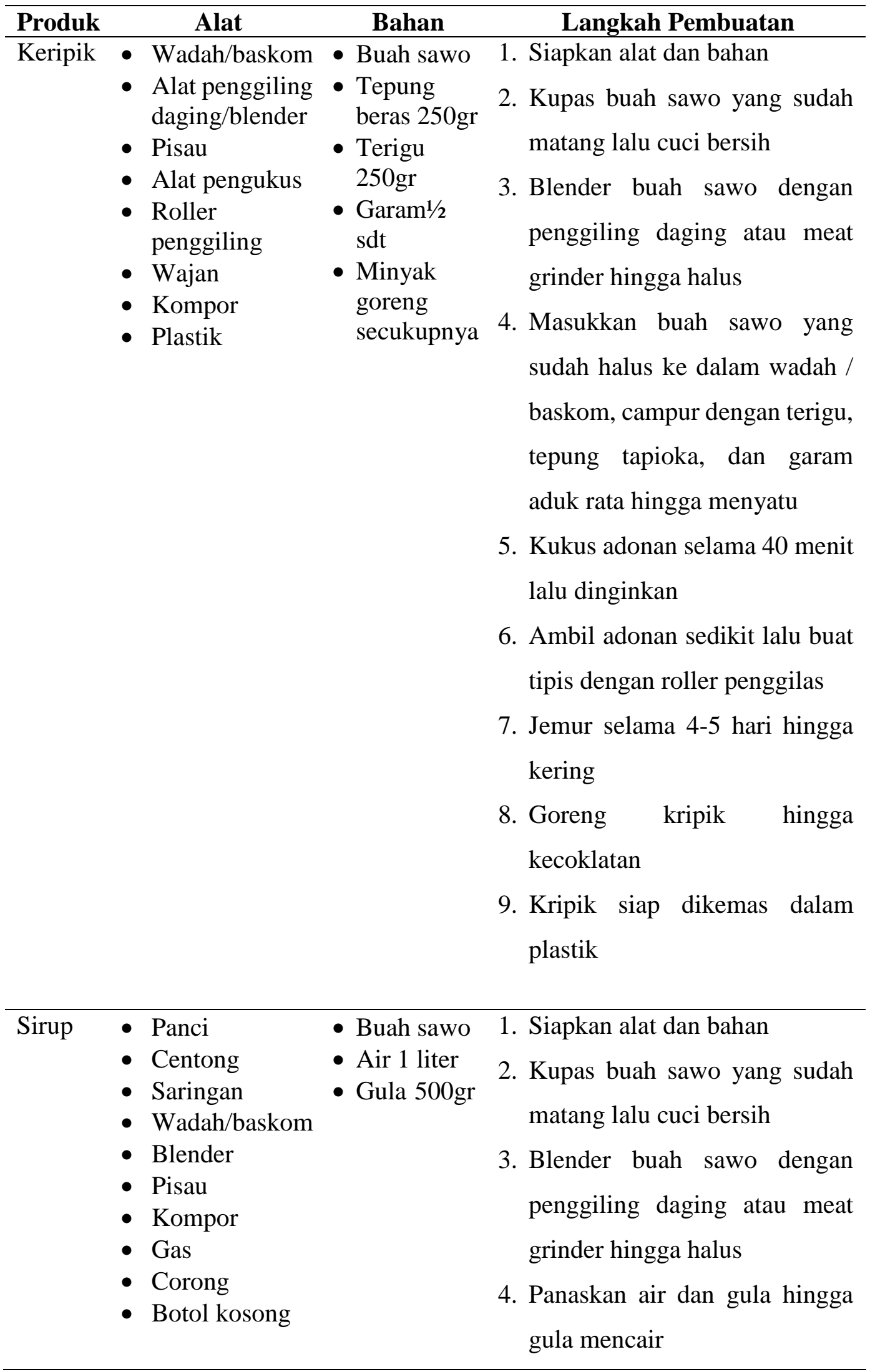


5. Masukkan buah sawo yang sudah halus kedalam panci berisi air gula, aduk terus menerus hingga mendidih lalu matikan kompor

6. Saring sirup buah sawo dengan penyaring yang halus

7. Tunggu hingga dingin lalu masukan ke dalam botol sebagai packaging

$\overline{\text { Setelah melakukan uji coba pembuatan produk keripik dan sirup sawo, produk }}$ dikemas untuk selanjutnya disosialisasikan ke Ibu-Ibu desa Pawidean.

Kegiatan kelima yaitu menentukan lokasi untuk melakukan sosialisasi produk olahan buah sawo menjadi keripik dan sirup sawo. lokasi yang digunakan untuk proses sosialisasi adalah di rumah salah satu warga.

Kegiatan keenam yaitu sosialisasi kepada Ibu-Ibu di desa Pawidean. Kegiatan sosialisasi ini dilakukan pada tanggal 24 November 2020 dimulai pada pukul 09.00 sampai dengan pukul 11.00 di rumah salah satu warga desa Pawidean. Kegiatan ini dihadiri oleh $15 \mathrm{Ibu}$ - Ibu warga Pawidean yang sebelumnya sudah diberikan undangan untuk menghadiri acara sosialisasi tersebut.

Kegiatan sosialisasi diawali dengan memberikan informasi tentang kandungan dan manfaat dari buah sawo. Setelah itu sosialisasi cara atau langkah pembuatan keripik dan sirup sawo. Setelah dilakukan sosialisasi kegiatan selanjutnya adalah uji coba produk sampel yang dibagikan ke peserta sosialisasi. Di akhir acara dilakukan tanya jawab dengan peserta terkait pengolahan buah sawo dijadikan produk keripik dan sawo. Produk yang dihasilkan dari kegiatan ini dapat dilihat pada gambar di bawah ini:

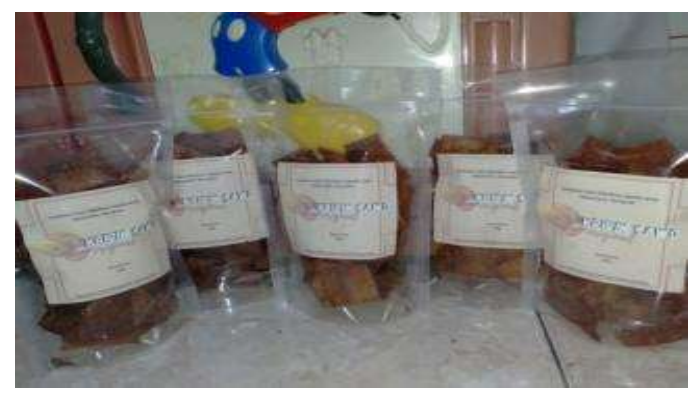

Gambar 2. Produk Keripik Sawo 
Keripik sawo merupakan makanan atau bisa disebut dengan cemilan yang dibuat dari bahan-bahan yang gampang dicari. Buah sawo mudah di dapatkan dipasar serta bahan-bahan yang lainnya seperti tepung terigu dan tepung beras yang tinggal beli di warung saja. Keripik sawo ini dibuat tanpa pengawet, tanpa pewarna, tanpa penambahan zat kimia lainnya, serta tanpa gula, dan bisa tahan 6-7 hari. Selain itu keripik sawo juga bisa menambah daftar cemilan yang ada dipasaran karena produknya yang jarang ditemukan. Keripik ini memikiki rasa renyah seperti keripik pada umumnya dan memiliki rasa manis yang asli di hasilkan dari manisnya buah sawo sehingga pembuatannya tanpa ada tambahan gula.

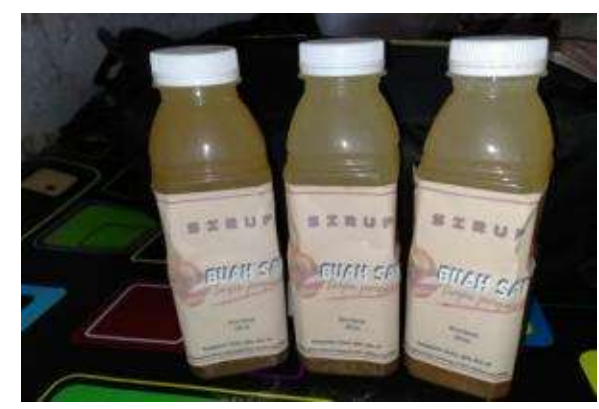

Gambar 1.4 Sirup Buah Sawo

Sirup sawo adalah minuman dengan gula asli dan rasa manis yang kuat. Minuman sirup sawo ini dihasilkan dari buah segar sawo yang dipadukan dengan gula pasir tentunya berkualitas dan juga higienis. Perpaduan dari sari buah sawo dan gula pasir membuat sirup ini dapat dinikmati saat cuaca panas maupun dingin. Sirup sawo ini juga dapat ditambahkan sengan sedikit air atau bisa juga di tambahkan es batu sehingga menambah rasa segar manis yang dingin.

\section{Kesimpulan}

Kegiatan penyuluhan atau sosialisasi di Desa Pawidean terlaksana dengan baik. Melalui kegiatan ini Ibu-Ibu memperoleh pengetahuan dan informasi tentang pengolahan dan memanfaatkan produk unggulan atau komoditas unggulan buah sawo menjadi produk keripik dan sirup. Kegiatan ini mendapatkan respon yang positif, tentunya hal ini dapat ditindaklanjuti pada waktu berikutnya.

\section{E. Ucapan Terima kasih}

Ucapan terimakasih kepada LPPM Universitas Wiralodra yang telah memfasilitasi tim untuk melakukan pengabdian kepada masyarakat. Terima kasih kepada semua pihak yang telah memberikan data dan membantu dalam pengabdian ini. 
ABDI WIRALODRA

JURNAL PENGABDIAN KEPADA MASYARAKAT
ISSN 2656-5501 (Print)

ISSN 2714-8041 (Online)

\section{Daftar Pustaka}

Amin, Muh., dan Muhammad Subri. 2018. Pelatihan Pembuatan Makananan Ringan Ekstrudat Jagung Guna Meningkatkan Pendapatan Masyarakat. Dalam jurnal pengabdian dan pemberdayaan masyarakat. Vol. 2 no.1 hal. 1 .

Harismi, Asni. 2019. Bisa Detoks Ini 6 Manfaat Buah Sawo yang Mencengangkan.

Hidayah I, 2010. Analisis Prioritas Komoditas Unggulan Perkebunan Daerah Kabupaten Baru (Pre-eminent Commodity Preference Analysis of Plantation of Sub-Provice Baru) AGRIKA Vol 4 (1).

Hendarmin, Metasari Kartika dan Wenny Pebrianti. 2018. Pelatihan dan Pendampingan Pengolahan Komoditi Kelapa. Jurnal Pengabdian dan Pemberdayaan Masyarakat. Vol. 2 no. 1 hal 2-3.

Irnandi. 2018. Peningkatan Ekonomi Masyarakat Melalui Pembuatan Keripik

Singkong Di Semuluh Kidul, Semanu, Gunung Kidul. Jurnal Berdikari. Vol. 6 no.1 hal 53-56.

Jauhari, Rahman. 2014. Usaha Industri Koktail Buah. Makalah. Dalam online Jufriyanto. 2019. Pengembangan Produk Unggulan Sebagai Potensi Peningkatan Ekonomi Masyarakat Desa di Kecamatan Modung Bangkalan. Jurnal ilmiah pengabdhi. Vol.5 no.1 hal 28-29.

Kusumiyati., dkk. 2017. Kualitas Sawo (Achras zapota L.) Kultivar Sukatali Selama Penyimpanan. Dalam jurnal Agrikultura. Vol 18 (2), Hal 90. Nurhidayati, Siti., Sri Ariani., dan Khaeruman Khaeruman. 2019. Pelatihan Pembuatan Mie Kering Dari Ubi Untuk Memaksimalkan Pemanfaatan Potensi Lokal Desa Durian Lombok Tengah. Jurnal abdi masyarakat. Vol 1 hal 51-52.

Puspita, Dhanang., dkk. 2018. Pemanfaatan Buah Sawo Keju (Pouteria Campechiana) Menjadi Mentega Sebagai Suplemen Vitamin A. Jurnal dunia gizi. Vol.1 no.2 hal 84 .

Rismunandar, 1983. Membudidayakan Tanaman Buah-buahan. Bandung: Sinar Baru.

Suhandy, Diding. 2009. Pendugaan Kandungan Padatan Terlarut Buah Sawo Menggunakan Nir Spectroscopy. Dalam jurnal Bionatura. Vol. 11 No.1 hal $1-2$. 